Research Article

\title{
Efficacy of Moringa Leaves Powder as a Supplement in Whole Wheat Flour Biscuit
}

\author{
Aysha Riaz* and Said Wahab
}

Department of Food Science and Technology, Faculty of Nutrition Sciences, the University of Agriculture, Peshawar, Khyber Pakhtunkhwa, Pakistan.

\begin{abstract}
Wheat flour biscuits are of widely consumed bakery products and mostly considered as nutritionally poor due to lacking in certain essential micronutrients. Moringa leaves are very rich in nutrients namely proteins, fibers and minerals. Keeping in view the nutritional importance of moringa leaves powder, the present study was carried out to investigate the effect of moringa leaves enrichment on the overall quality of whole wheat flour biscuits. Composite flours were made by incorporating moringa leaves powder in different ratios (2, 4, 6, 8 and 10\%) in whole wheat flour. Biscuits were prepared from the composite flours and were analyzed for physical attributes, proximate composition and sensory evaluation. The results showed that moringa leaves powder have higher protein content, crude fat, ash content and crude fiber whereas lower NFE content compared to whole wheat flour. In moringa leaves powder and whole wheat flour, the protein, fat, ash, fiber and NFE contents were 23.27 and $12.48,8.49$ and 1.48, 12.98 and 1.33, 12.64 and 2.41 and 34.60 and $75.15 \%$ respectively. The farinograph water absorption and mixing tolerance index of wheat-moringa composite flour increased whereas the dough stability decreased with increasing the proportion of moringa leaves powder. Width and spread ratio of the biscuits decreased and the thickness of the biscuits increased with increasing the enrichment level of moringa leaves powder. The moisture content of the biscuits was in the range of 3.99 to $4.13 \%$, protein content, crude fat, ash content, crude fiber and NFE content of $\mathrm{WMB}_{0}$ (biscuits with $100 \%$ whole wheat flour and $0 \%$ moringa leaves powder) and $\mathrm{WMB}_{10}$ (biscuits with $90 \%$ whole wheat flour and $10 \%$ moringa leaves powder) were 7.58 and 8.65, 23.42 and $25.44,1.28$ and 2.09, 1.09 and 3.60, and 62.67 and 56.15\% respectively. There was $12.37 \%$ crude protein content, $7.95 \%$ in crude fat, $38.81 \%$ increase in ash content and $70.38 \%$ in crude fiber of the biscuits whereas, the NFE content increased by $11 \%$. The sensory attributes were recorded to be in the acceptable range with the enrichment of moringa leaves powder. Moringa leaves are the rich source of proteins, minerals and fibers and could be used as supplementary materials to enhance the nutritional profile of biscuits and other bakery products in the baking industries.

Received | March 13, 2020; Accepted | March 15, 2021; Published | May 28, 2021

*Correspondence | Aysha Riaz, The University of Agriculture Peshawar, Khyber Pakhtunkhwa, Pakistan; Email: ayshariaz@aup.edu.pk

Citation | Riaz, A. and S. Wahab. 2021. Efficacy of moringa leaves powder as a supplement in whole wheat flour biscuit. Sarhad Journal of Agriculture, 37(2): 573-585.

DOI | https://dx.doi.org/10.17582/journal.sja/2021/37.2.573.585

Keywords | Whole wheat flour, Moringa leaves powder, Biscuit, Proximate composition, Sensory evaluation
\end{abstract}

June 2021 | Volume 37 | Issue 2 | Page 573 


\section{Introduction}

$\mathrm{W}$ Theat, the mainstay of human beings, is an important source of energy, besides a supplier of different nutrients and micronutrients necessary for a healthy diet. However, wheat processing significantly affects the nutritional pattern of wheat grain and leads to loss of nutrients and reduces nutritive value of wheat flour (Rosell, 2012; Narwal et al., 2020). Wheat flour is used in the form of bread, biscuit, noodles, pasta etc. As the wheat flour is deficient in specific macro and micronutrients, so efforts are made to fortify or enrich wheat flour (Latunde-Dada et al., 2019) and wheat flour products with legumes (Turfani et al., 2017; Dauda et al., 2018; Zhang et al., 2018; Boukid et al., 2019), nuts (Ocheme et al., 2018), other cereal (Basman and Köksel, 2001; Pande et al., 2017) or vegetable sources (Díaz et al., 2019) with the aim to increase protein (Nogueira and Steel, 2018; Boukid et al., 2019), or fiber (Turfani et al., 2017) or micronutrients (Pande et al., 2017).

The word biscuit is derived from Latin word which means "twice cooked" as the biscuits are first cooked and then slow dried to harden (Manley,2011). Biscuits are small, cereal-based, sweetened, baked products (Miller et al., 2016; Manley, 2011) and are widely consumed snacks due to their pleasant aroma and taste. Biscuits are broadly classified into hard dough, soft dough and wafers (Miller et al., 2016) and considered as the traditional products consumed throughout the world, by the people of all socioeconomic groups and age (Nogueira and Steel, 2018; Gandhi et al., 2001). The widespread use of biscuit can be attributed to longer shelf life allowing large scale production, convenient handeling, sensorial properties and added value. In general biscuits are used as snack food for their pleasant aroma and taste. Usually they are used as an energy source and not as an element of nutrition. Biscuits with health and nutrition claims are now gaining popularity in the market. Biscuits claiming reduced or no calories (with no or low sugar and/or fat), and enriched with particular macro or micronutrient or functional ingredients such as fibers, proteins, vitamins and minerals are gaining much attention (Nogueira and Steel, 2018).

Moringa (Moringa Oleifera) is a rich source of proteins, minerals, vitamins and antioxidants with a relatively low amount of anti-nutritional factors. It is considered as a multipurpose tree which has great potential. It has been reported that this tree can help improve food security and reduce malnutrition (Domenico et al., 2018). Moringa leaves powder has been used in preparation of cookies using fine flour (Dachana et al., 2010). The aim of the current study was to enrich whole wheat flour biscuits using moringa leaves powder. The physical attributes, proximate composition and sensory properties of the enriched biscuits were studies.

\section{Materials and Methods}

The research study was carried out in the Department of Food Science and Technology, The University of Agriculture Peshawar Pakistan. Sample of wheat grains (Pirsabak-13 cv.) was obtained from the Department of Agronomy, The University of Agriculture Peshawar. The grains were cleaned and milled into flour using laboratory-scale mill (Thomas-Wiley, Model 4.USA). Moringa leaves were taken from "Medicinal and Aromatic Plants Garden” Department of Agronomy, The University of Agriculture Peshawar. The leaves were washed thoroughly, dried under shade and then grinded using an electric grinder (Ewulo et al., 2017). The whole wheat flour and moringa leaves powder were passed through 50 mesh size sieve to equilibrate the particle size. The whole wheat flour and moringa leaves powder were then stored in plastic bags for further analysis and research work. Whole wheat flour and moringa leaves powder were blended in different ratios as given in Table 1 .

Table 1: Blends of whole wheat flour and moringa leaves powder.

Whole wheat flour (\%) Moringa leaves powder (\%)

$\begin{array}{lll}\mathrm{WM}_{0} & 100 & 0 \\ \mathrm{WM}_{2} & 98 & 2 \\ \mathrm{WM}_{4} & 96 & 4 \\ \mathrm{WM}_{6} & 94 & 6 \\ \mathrm{WM}_{8} & 92 & 8 \\ \mathrm{WM}_{10} & 90 & 10\end{array}$

\section{Rheological properties}

For determination of rheological properties of the composite flour Brabender farinograph (Model $\mathrm{T}$ 150 E, Duisburg, Germany) was used. The rheology was determined by the method of AACC (2010).

\section{Preparation of biscuit}

Biscuits were prepared by replacing the whole wheat June 2021 | Volume 37 | Issue 2 | Page 574 
flour with moringa leaves powder in different ratios (Table 2) according to the approved method of AACC (2010).

Table 2: Preparation of biscuit with different proportions of wheat flour and Moringa leaves powder.

\begin{tabular}{|c|c|c|c|c|c|c|}
\hline & $\mathrm{WMB}_{0}$ & $\mathrm{WMB}_{2}$ & $\mathrm{WMB}_{4}$ & $\mathrm{WMB}_{6}$ & $\mathrm{WMB}_{8}$ & $\mathrm{WMB}_{10}$ \\
\hline $\begin{array}{l}\text { Wheat } \\
\text { Flour (g) }\end{array}$ & 500 & 490 & 480 & 470 & 460 & 450 \\
\hline $\begin{array}{l}\text { Moringa } \\
\text { leaves pow- } \\
\text { der (g) }\end{array}$ & 0 & 10 & 20 & 30 & 40 & 50 \\
\hline Sugar (g) & 250 & 250 & 250 & 250 & 250 & 250 \\
\hline $\begin{array}{l}\text { Solid Fat } \\
\text { (g) }\end{array}$ & 250 & 250 & 250 & 250 & 250 & 250 \\
\hline Egg (No) & 2 & 2 & 2 & 2 & 2 & 2 \\
\hline $\begin{array}{l}\text { Baking } \\
\text { powder(g) }\end{array}$ & 10 & 10 & 10 & 10 & 10 & 10 \\
\hline
\end{tabular}

Where; $W M B_{0}$ : biscuit with 100\% wheat flour; $W M B_{2}$ : biscuit with 98\% wheat flour and $2 \%$ Moringa leaves powder; $W M B_{4}$ biscuit with 96\% wheat flour and 4\% Moringa leaves powder; $W M B_{6}$ : biscuit with 94\% wheat flour and 6\% Moringa leaves powder; $W M B_{8}$ : biscuit with 92\% wheat flour and 8\% Moringa leaves powder $W M B_{10}$ : biscuit with 90\% wheat flour and 10\% Moringa leaves powder.

\section{Physical attribute}

The prepared biscuits were investigated for physical attributes such as thickness, width and spread ratio following the standard methods of AACC (2010).

\section{Proximate composition}

Whole wheat flour and moringa leaves powder were taken as such, whereas the biscuits were ground to form a powder for proximate analysis. Proximate composition of the whole wheat flour, moringa leaves powder and the biscuits were analyzed by the method of AACC (2010).

\section{Sensory attributes}

Sensory characteristics like flavor, color, texture, and overall acceptability of the prepared cookies were judged by a panel of judges according to the method of Larmond (1997) using 9-point hedonic scale.

\section{Statistical analysis}

The data obtained from this study were analyzed statistically according to the standard method as described by Steel and Torrie (1960). Data were subjected to complete randomized block design (CRD), and means were separated by LSD using software Statistix 8.1.

\section{Results and Discussion}

Proximate composition of flours: Proximate composition of the whole wheat flour and moringa leaves powder is presented in Figure 1. The Figure clearly shows the difference in the composition of whole wheat flour, and moringa leaves powder. Moringa leaves powder has higher protein, fat, ash and fiber content compared to whole wheat flour.

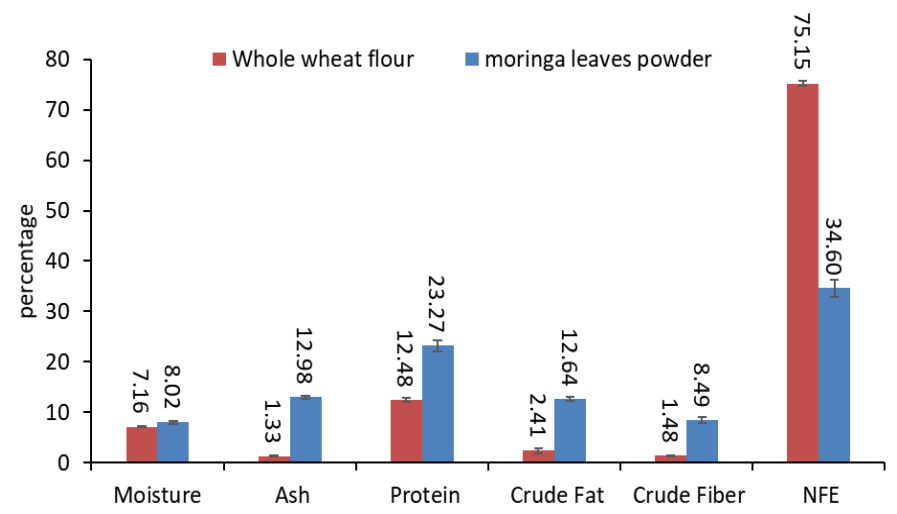

Figure 1: Proximate composition of whole wheat flour and moringa leaves powder.

The moisture content of whole wheat flour was recorded as $7.16 \%$ and that of moringa leaves powder as $8.02 \%$. There was a slight difference in the moisture content of the flour and powder. A slightly higher moisture content of wheat flour was observed by Miller et al. (2016). The moisture content of whole wheat flour as observed by Kaur et al. (2017) was $12.15 \%$ which is higher than the present study. The difference in moisture content of the flour may be due the tempering and milling conditions of flour. Shokery et al. (2017) reported similar moisture content (8.81\%) of dried moringa leaves powder. The lower moisture content of the leaves powder make it shelf stable and the leaves can be stored for a considerable length of time (up-to 1 year) at room temperature when packed properly. The ash content was $1.33 \%$ for whole wheat flour and $12.98 \%$ for moringa leaves powder. Similar ash content was also observed by Kaur et al. (2017) in whole wheat flour. Ash content of 0.96\% was reported by Miller et al. (2016) in wheat flour. Our values for ash content of moringa leaves powder are in agreement with those of Sánchez-Machado et al. (2010) who reported ash content of $14.2 \%$ for moringa leaves on a dry weight basis. The higher ash content is valuable in terms that it may increase the mineral content of diet when it is supplemented in low ash foods such as wheat. High ash flours may be undesirable in bread production because it may result 
in reduced loaf volume, but its use in biscuit and pasta may increase the sensory acceptability of the product (Miller et al., 2016).

The protein content was high in moringa leaves powder (23.27\%) and lower in whole wheat flour (12.48\%). The results of protein content for whole wheat flour are in agreement with those of Kaur et al. (2017) who recorded $11.52 \%$ of protein content in whole wheat flour. Miller et al. (2016) reported similar values of protein content (12.81) for wheat flour. Similar protein content of $24.7 \%$ and $25.1 \%$ for dried moringa leaves was observed by Shokery et al. (2017) and Makkar and Becker (1996). A protein content of $22.42 \%$ on dry weight basis of moringa leaves was also observed by Sánchez-Machado et al. (2010). The results of this study are also in line with Nouman et al. (2016) who carried out a study on different varieties of moringa grown in Pakistan and found that the protein content of the varieties was in the range of $22.19-31.35 \mathrm{~g} / 100 \mathrm{~g}$. It has been stated in a review that the protein content of moringa leaves is in the range from 10.74 to $30.29 \mathrm{~g} / 100 \mathrm{~g}$ (Falowo et al., 2018). The variation in the values observed in this study and those reported earlier could be due to different agroclimatic factors. A great variation has been reported for the protein content of moringa genotypes from the same specie (Hassanein, 2018). The higher protein content of dried moringa leaves indicates that it could be used as a valuable protein source in human diets as well as animal feeds. This can also reduce the dependency on foreign sources of dietary proteins (Mendieta-Araica et al., 2011). Replacement of plant protein with animal protein is also essential to reduce the dependency on animal protein with the aim to reduce the greenhouse effect and environmental stress associated with animal production (Domenico et al., 2018). The crude fiber content of whole wheat flour was $2.41 \%$ and that of moringa leaves powder was $12.64 \%$. A similar value of crude fiber was also reported by Gammal et al. (2016) who reported a crude fiber content of $2.5 \%$ for wheat flour. Shokery et al. (2017) recorded $11.28 \%$ of crude fiber in dried moringa leaves which is in agreement with the present results. Fiber is very beneficial in reducing the risk of certain diseases such as diabetes, cardiovascular ailments and obesity. It also prevents the occurrence of colorectal cancer (Liu et al., 2011). The higher fiber content of moringa leaves powder increases its potential to be used as functional ingredient in food formulation such as baked goods. Crude fat content was $1.48 \%$ for whole wheat flour and $8.49 \%$ for moringa leaves powder. Fat content in wheat flour was in agreement with Miller et al. (2016) who observed $1.53 \%$ of crude fat in wheat flour. A slightly higher fat content (2.3\%) was observed in whole wheat flour by Kaur et al. (2017). Higher fat content was reported by Yaméogo et al. (2011) for moringa leaves powder. The fat content of the moringa leaves contains all the essential fatty acids and the presence of polyunsaturated fatty acid is high as compared to the monounsaturated fatty acids (Sánchez-Machado et al.,2010). Nitrogen free extract (NFE) was higher in whole wheat flour and lower in moringa leaves powder. The carbohydrate content of the whole wheat flour was recorded as $75.15 \%$ while those of moringa leaves powder was $34.60 \%$. Similar results of NFE (74.47\% and 70.92\%) for wheat flour were also reported by Rebellato et al. (2015) and Gammal et al. (2016). Sánchez-Machado et al. (2010) reported slightly lower amount of carbohydrates (27.05\%) in moringa leaves on dry weight basis.

The variation in moringa leaves powder composition found in this study and literature may be due to agroclimatic conditions (Makkar and Becker, 1996). The quality of moringa leaves is also affected by age and cultivation practices (Murwa et al., 2017). Moringa leaves powder being rich in proteins, fibers and minerals can be used as multifunctional food fortificant.

\section{Dough rheology of the whole wheat and moringa leaves powder composite flour}

The rheological data of the whole wheat and moringa leaves composite flour is presented in Figure $2 \mathrm{a}$ and 2b. Graph 'a' shows the water absorption and mixing tolerance of the composite flour. It is clear from the graph that there is a slight increase in the water absorption of the composite flour with increasing level of moringa leaves powder. The mixing tolerance index (MTI) increased from 36 to 85FU. The dough stability and dough development time are given in Figure $2 \mathrm{~b}$. The dough stability decreased from 7.1 to $3.2 \mathrm{~min}$. The DDT was in the range of 5.7 to $6.4 \mathrm{~min}$. There is less increase in the water absorption capacity of the dough and the dough development time changed non-significantly which is shown by nearly straight lines (Graph b). The results for water absorption agree with that of Dachana et al. (2010) who reported a significant increase in the water absorption capacity of wheat moringa flour (59.2-66.7\%). Dachana et al. 
(2010) also used moringa leaves powder to enrich biscuits, in their study the value of water absorption for control biscuits was lower than our findings. The reason for it may be that they used fine wheat flour and we used whole wheat flour, the water absorption of the whole wheat flour is higher due to the presence of high amount of bran (fibers). The findings of Premi and Sharma (2018) also support our results who studied the dough rheology of wheat moringa composite flour for making cake. These authors observed an increase in water absorption and MTI and a decrease in the dough strength. They attributed the increase in the water absorption of the dough to the high fiber and protein content of moringa leaves. This fact is supported by the results of Villemejane et al. (2013) who noted an increase in the water absorption of fiber-enriched doughs. According to Villemejane et al. (2013) the effect of fiber is not merely due to the total dietary fiber content but also on their solubility. The influence of fiber content on the water absorption of the dough may be due to its nature to absorb water leading to competition with other dough ingredient such as gluten and damaged starch. Whereas the data for MTI is in agreement with that of Dachana et al. (2010). A similar trend in the increase of water absorption and decrease in dough stability and increase in mixing tolerance is also reported for the addition of Murraya koenigii and Tinospora cordifolia leaf powders to wheat flour (Drisya et al., 2015; Sharma et al., 2013). Rajiv et al. (2012) studied the effect of green gram flour replacement with wheat flour on the rheological properties of the dough and noted an increase in water absorption and decrease in the dough stability. The author explained the increased water absorption as the effect of high absorption capacity of the green gram flour. The mixing profile is significantly altered by the addition of moringa leaves powder, this may be attributed to the dilution of gluten, increase of fibers and other components of moringa leaves powder. These results are also confirmed by the study of Srivastava et al. (2014) who studied the dough rheology of flour with added pomegranate peel powder. These authors explained the change in the dough rheology as the increase in fiber content of the composite four. The decrease in the MTI indicates the weakening strength of the dough. The MTI has an inverse relation with the dough stability. As the MTI increase the dough stability is decreased. This relation is clearly revealed in the Figure 2 by the lines with an increasing trend for MTI and a decreasing trend for dough stability.
The dough stability decreases due to the decrease in the gluten content of the composite flour.
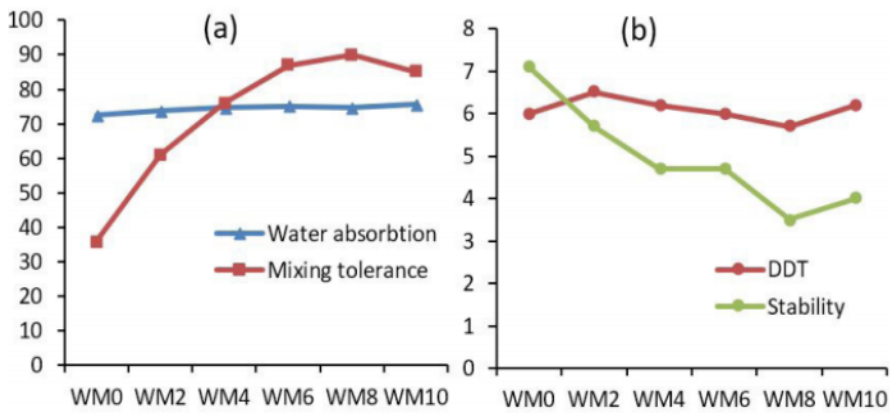

Figure 2: (a) water absorption and mixing tolerance of wheat Moringa composite flour (b) dough development time and dough stability of wheat Moringa composite flour.

WM : 100\% wheat flour; WM : 98\% wheat flour and 2\% Moringa leaves powder; WM: $96 \%$ wheat flour and 4\% Moringa leaves powder; WM: $94 \%{ }^{4}$ wheat flour and 6\% Moringa leaves powder; WM: $92 \%$ wheat flour and 8\% Moringa leaves powder; WM : $90 \%{ }^{8}$ wheat flour and $10 \%$ Moringa leaves powder.

\section{Physical attributes of biscuits}

The physical properties of the control and enriched biscuits are given in Table 3. Control biscuits $\left(\mathrm{WMB}_{0}\right)$ has the highest value for width $(57.33 \mathrm{~mm})$ and the biscuits supplemented with $10 \%$ moringa leaves powder $\left(\mathrm{WMB}_{10}\right)$ has the lowest value $(53.53 \mathrm{~mm})$. With increasing the supplementation level of moringa leaves powder, the width of the biscuits decreased. Other researchers also reported a decrease in the width (diameter) of cookies by the addition of high fiber supplements (Sharif et al., 2009; Ajila et al., 2008; Sudha et al., 2007). A decrease in the width of the cookies from 87.3 to $81.5 \mathrm{~mm}$ was also observed in research where wheat flour was replaced with Murraya koenigii leaves powder (Drisya et al., 2015). The results also confirmed the observations of Dachana et al. (2010) who noted a decrease in diameter of cookies supplemented with dried moringa leaves powder. Kulthe et al. (2014) also recorded a reduction in the width $(35.4-34.9 \mathrm{~mm})$ of cookies supplemented with defatted soy flour. Protein enrichment brings a change in the dimensions of the biscuits (Nogueira and Steel, 2018).

The maximum mean value for thickness was recorded for $\mathrm{WMB}_{10}$ and the minimum value was recorded for $\mathrm{WMB}_{0}$. The thickness of the biscuits increased with an increasing level of moringa leaves powder. Other researches also reported similar results. Dachana et al. (2010) reported cookie thickness to increase from 12.5 to $13 \mathrm{~mm}$ for moringa leaves supplemented cookies. Drisya et al. (2015) observed an increase in 
the thickness of the cookies from 11 to $13 \mathrm{~mm}$ while supplementing Murraya koenigii leaves powder. Kulthe et al. (2014) prepared cookies with supplementation of defatted soy flour and noticed an increase in the thickness of the cookies from 7 to $7.6 \mathrm{~mm}$. Sharif et al. (2009) also recorded an increase in the thickness of cookies. It has been observed in other researches that using supplements with high fiber and high protein content increases the thickness of the cookies (Rebellato et al., 2015).

Table 3: Physical properties of control and supplemented biscuits.

$\begin{array}{llll} & \text { Width }(\mathbf{m m}) & \text { Thickness }(\mathbf{m m}) & \text { Spread ratio } \\ \text { WMB0 } & 57.33 \pm 0.83^{\mathrm{a}} & 10.90 \pm 0.63^{\mathrm{d}} & 5.26 \pm 0.23^{\mathrm{a}} \\ \text { WMB2 } & 55.97 \pm 1.10^{\mathrm{ab}} & 11.31 \pm 0.85^{\mathrm{cd}} & 4.95 \pm 0.39^{\mathrm{ab}} \\ \text { WMB4 } & 55.00 \pm 0.58^{\mathrm{bc}} & 11.82 \pm 0.75^{\mathrm{bcd}} & 4.65 \pm 0.28^{\mathrm{bc}} \\ \text { WMB6 } & 54.25 \pm 1.75^{\mathrm{bc}} & 12.56 \pm 0.60^{\mathrm{abc}} & 4.32 \pm 0.28^{\mathrm{d}} \\ \text { WMB8 } & 54.17 \pm 1.18^{\mathrm{bc}} & 12.91 \pm 0.75^{\mathrm{ab}} & 4.20 \pm 0.34^{\mathrm{cd}} \\ \text { WMB10 } & 53.58 \pm 1.99^{\mathrm{c}} & 13.22 \pm 0.71^{\mathrm{a}} & 4.05 \pm 0.28^{\mathrm{d}}\end{array}$

Different superscript letters within column with different letters in the column show significant difference at 5\% level of significance. $W M B_{0}$ : biscuit with 100\% wheat flour; $W M B_{2}$ : biscuit with 98\% wheat flour and 2\% Moringa leaves powder; $W M B_{4}$ biscuit with 96\% wheat flour and 4\% Moringa leaves powder; $W M B_{6}$ : biscuit with 94\% wheat flour and 6\% Moringa leaves powder; $W M B_{8}$ : biscuit with 92\% wheat flour and 8\% Moringa leaves powder $W M B_{10}$ : biscuit with 90\% wheat flour and 10\% Moringa leaves powder.

The spread ratio was recorded as highest for control $\left(\mathrm{WMB}_{0}\right)$ biscuits and lower for $10 \%$ supplemented biscuits $\left(\mathrm{WMB}_{10}\right)$. The data shows that the spread ratio of the biscuits decreased as the concentration of the moringa leaves powder increased in the biscuits.
Drisya et al. (2015) observed a decrease of 7.40 to 6.22 in cookies supplemented with Murraya koenigii leaves powder. Same results were observed by Dachana et al. (2010) who reported a decrease of spread ratio from 7.10 to 6.52 in cookies supplemented with moringa leaves powder. Our results are also in agreement with those of Kulthe et al. (2014) who recorded a reduction in the spread ratio from 5.1 to 4.6 in cookies supplemented with defatted soy flour. The decrease in the spread ratio of the biscuits is due to the decrease in width and increase in thickness of the biscuits. The spread ratio of cookies prepared by the addition of defatted rice bran also decreased because of the presence of high content of fibers (Sharif et al., 2009). The lower spread ratio of biscuit indicates an increase in rising ability of cookies (Cheng and Bhat, 2016). So the lower value (4.05) of spread ratio for the $10 \%$ moringa leaves enriched biscuits as compared to control (5.26) shows that enrichment increased the rising ability of the biscuits. It has been reported by researchers that during dough mixing there may exist competition among the gluten and other ingredients of the flour which may result in decrease of spread factor (Nasir et al., 2010). Another reason for the decrease of spread factor of the biscuits is that the composite flours form aggregates which increase the hydrophilic sights and in turn the compition for the little frree water available in the dough. Rapid partitioning of the free water into these hydrophylic sightsduring dough mixing increases viscosity thereby reducing spread ratio of the biscuits (Hooda and Jood, 2005). Flour or other ingredients which absorbs water during dough mixing decrease spread ratio (Dachana et al., 2010).

Table 4: Proximate composition of control and supplemented biscuits.

\begin{tabular}{|c|c|c|c|c|c|c|}
\hline Treatment & Moisture (\%) & Ash (\%) & Crude fiber (\%) & Crude fat (\%) & Crude protein (\%) & NFE (\%) \\
\hline $\mathrm{WMB}_{0}$ & $3.99 \pm 0.20$ & $1.28 \pm 0.03^{f}$ & $1.07 \pm 0.07^{\mathrm{f}}$ & $23.42 \pm 0.25^{\mathrm{d}}$ & $7.58 \pm 0.18^{\mathrm{e}}$ & $62.67 \pm 0.22$ \\
\hline $\mathrm{WMB}_{2}$ & $4.11 \pm 0.16$ & $1.39 \pm 0.05^{\mathrm{e}}$ & $1.55 \pm 0.09^{\mathrm{e}}$ & $23.76 \pm 0.27^{\mathrm{cd}}$ & $7.77 \pm 0.23^{\text {de }}$ & $61.42 \pm 0.41$ \\
\hline $\mathrm{WMB}_{4}$ & $4.06 \pm 0.41$ & $1.51 \pm 0.03^{\mathrm{d}}$ & $2.08 \pm 0.10^{\mathrm{d}}$ & $24.15 \pm 0.78^{\mathrm{bc}}$ & $7.91 \pm 0.11^{\mathrm{cd}}$ & $60.29 \pm 1.11$ \\
\hline $\mathrm{WMB}_{6}$ & $4.13 \pm 0.20$ & $1.79 \pm 0.05^{\mathrm{c}}$ & $2.65 \pm 0.07^{c}$ & $24.75 \pm 0.11^{\mathrm{ab}}$ & $8.17 \pm 0.17^{\mathrm{bc}}$ & $58.51 \pm 0.14$ \\
\hline $\mathrm{WMB}_{8}$ & $4.11 \pm 0.31$ & $1.99 \pm 0.04^{b}$ & $3.20 \pm 0.04^{\mathrm{b}}$ & $25.12 \pm 0.14^{a}$ & $8.41 \pm 0.16^{\mathrm{ab}}$ & $57.18 \pm 0.12$ \\
\hline $\mathrm{WMB}_{10}$ & $4.08 \pm 0.11$ & $2.09 \pm 0.08^{\mathrm{a}}$ & $3.60 \pm 0.11^{\mathrm{a}}$ & $25.44 \pm 0.41^{\mathrm{a}}$ & $8.65 \pm 0.14^{a}$ & $56.15 \pm 0.42$ \\
\hline$\%$ increase/ decrease & - & $38.81 \uparrow$ & $70.38 \uparrow$ & $7.95 \uparrow$ & $12.37 \uparrow$ & $11 \downarrow$ \\
\hline
\end{tabular}

Different superscript letters within column with different letters in the column show significant difference at $5 \%$ level of significance. WMB : biscuit with 100\%wheat flour; WMB : biscuit with 98\% wheat flour and2\% Moringa leaves powder; WMB; biscuit with $96 \%$ wheat flour and 4\% Moringa leaves powder; $W M B_{6}$ : biscuit with 94\% wheat flour and 6\% Moringa leaves powder; WMB $:$ biscuit with $92 \%$ wheat flour and $8 \%$ Moringa leaves powder $W M B_{10}$ biscuit with 90\% wheat flour and 10\% Moringa leaves powder. $\uparrow$ shows percent increase; $\downarrow$ shows percent decrease. 
Proximate composition of biscuits

The proximate composition of control and supplemented biscuits are given in Table 4. The table reflects that the moisture, ash, crude fiber, crude fat and protein content increased while carbohydrates decreased with increasing concentrations of the moringa leaves powder.

\section{Moisture}

The biscuits were analyzed for moisture content which is presented in Table 4. Minimum moisture (3.98\%) content was recorded for control $\mathrm{WMB}_{2}$ biscuit, whereas maximum moisture content $(4.23 \%)$ was recorded for $\mathrm{WMB}_{6}$. Our results are in agreement with the result of Drisya et al. (2015) and Sharma et al. (2013) who reported 3.61\% to 3.95\% and 3.3 to $4.53 \%$ moisture content in cookies using Murraya koenigii leaves and Guduchi leaf powder respectively. Moisture content of 4.18 to $4.95 \%$ was also observed by Kaur et al. (2017) using flaxseed flour as supplement in biscuit preparation. Moisture content is important because it affects the storage life and it is also considered as the identity standard (Bradley, 2010). The observed moisture content of the supplemented biscuit is acceptable as the moisture content of biscuits is said to be less than $5 \%$ and suggests that these can be stored for an extended period when compared with the moisture content of shelf-stable foods.

\section{Ash content}

Ash content of the biscuits increased with increasing supplementation level of moringa leaves powder, the lowest value was recorded for $\mathrm{WMB}_{0}(1.28 \%)$ and the highest value for $\mathrm{WMB}_{10}(2.09 \%)$. The increase in ash content is due to the higher ash content of the moringa leaves powder indicating higher mineral content in the cookies. Dachana et al. (2010) reported an increase of ash content from 0.9 to $1.5 \%$ with an increase of moringa leaves powder from 0 to $10 \%$ in cookies. An increase of ash content from 1.98 to 3.65 $\%$ was also observed by Gammal et al. (2016) using moringa leaves powder in pan bread. An increase in ash content of the supplemented biscuits was also observed by Galla et al. (2017) and Drisya et al. (2015) using dried spinach powder (2.06-4.87\%) and dried Murraya koenigii (1.05-1.67\%) leaves powder, respectively. An increase in the ash content from $2.3-4.9 \%$ and $2.8 \%$ in cookies supplemented with green and yellows tea leaves respectively was also reported by Gramza-Michałowska et al. (2016).
All these researchers suggest that using leaves as supplement in biscuits increases the ash content of biscuits significantly. Other studies also conclude that using any supplement having higher ash content than wheat flour would tend to increase the ash content of the biscuits (Cheng and Bhat, 2016; Kaur et al., 2017; Dauda et al., 2018).

\section{Crude fiber}

Table 4 shows a minimum value of $1.07 \%$ crude fiber for $\mathrm{WMB}_{0}$ which increased to $3.60 \%$ in $\mathrm{WMB}_{10}$. The increase in the crude fiber of the enriched biscuits may be due to the higher fiber content of the moringa leaves powder. Same results of an increase in fiber content ( 0.89 to $2.31 \%$ ) were obtained for the biscuits supplemented with spinach powder (Galla et al., 2017). Our values of fiber content for control biscuits were higher than the biscuit supplemented with spinach powder because we used whole wheat flour. The results of our study are in agreement with those of Ismail et al. (2014) who reported an increase in the fiber content of cookies due to the supplementation of pomegranate peel powder which had a higher content of fiber as compared to wheat flour. Incorporation of defatted rice bran up to a level of $10 \%$ also increases the fiber content $(2.56-4.25 \%)$ of biscuits (Sharif et al., 2009). Contrary to our findings Dauda et al. (2018) reported a decrease in the fiber content of the biscuit while supplementing the biscuit with defatted groundnut paste. The reduction in fiber content of their study may be due to the lower fiber content of the defatted groundnut paste. Dietary fiber is an edible constituent of plants which is resistant to digestion and absorption in small intestine, and small portion is fermented in the large intestine. These include the non-starch polysaccharide, gums, pectin some hemicellulose and the resistant starches as well (Sharif et al., 2009). In the present study there was $70.38 \%$ increase in the fiber content of biscuits. This may impart a beneficial effect on consumer health.

\section{Crude fat}

The crude fat content of the control and enriched biscuits is given in Table 4. Data presented in the table depicts that the control biscuits $\left(\mathrm{WMB}_{0}\right)$ have the minimum content of crude fat with a value of $23.42 \%$. The higher percentage of fat content was found in $\mathrm{WMB}_{10}$ which contained $10 \%$ moringa leaves powder. A similar range of $21.27 \%-23.17 \%$ of crude fat was also reported in biscuit supplemented with buckwheat flour (Baljeet et al., 2010). An increase in 
the fat content $(25.38-28.12 \%)$ of biscuits was also observed by Dauda et al. (2018), they incorporated defatted groundnut paste in the preparation of biscuit. A close value of fat content of $26.54-25.67 \%$ was reported for jering legume flour supplemented biscuits (Cheng and Bhat, 2016). In contrast to our findings Sharma et al. (2013) observed a fat content of 17.24 to $16.865 \%$ for guduchi leaf powder enriched biscuits. The range of fat content was lower than our findings, this might be the effect of lower fat in their formula and lower fat content of guduchi leaf powder. The increase in fat content of biscuits in the present research study may be attributed to the higher fat content of the moringa leaves powder compared to whole wheat flour.

\section{Protein Content}

The data presented in Table 4 represents the protein content of the control and supplemented biscuits. The observations show that as the level of supplementation of moringa leaves powder is increased the protein content of the biscuits increase with a higher protein content of $8.65 \%$ recorded for $\mathrm{WMB}_{10}$ (supplemented with $10 \%$ Moringa leaves powder). Similar results of an increase in protein content from 7.83 to $9.05 \%$ and 5.88 to $10.79 \%$ were also reported by the use of dried Tinospora cordifolia leaf powder and spinach powder respectively in the preparation of biscuit (Sharma et al., 2013; Galla et al., 2017). An increase in the protein content (7.86-8.30\%) was also observed when sponge cake was supplemented up to $10 \%$ of moringa leaves powder (Premi and Sharma, 2018). The results observed in our research are in agreement with those of Kaur et al. (2017) and Cheng and Bhat (2016) who also reported an increase in the protein content of $7.40-8.14 \%$ and $6.82-7.92 \%$ of biscuits supplemented with flaxseed flour and jering legume flour (having higher protein content than wheat flour). Proteins are required for the repair, growth and maintenance of the body in children. It also acts as enzymes, hormones and maintains body electrolyte and acidbase balance (Adeola and Ohizua, 2018). The higher protein content of biscuits supplemented with $10 \%$ moringa leaves powder suggest a higher nutritional value of the biscuits.

\section{Carbohydrates (NFE)}

The carbohydrate content, which was determined by the subtraction method and presented as nitrogen-free extract (NFE), is given in Table 4. Minimum NFE (55.73\%) was observed for biscuit supplemented with
$10 \%$ moringa leaves powder $\left(\mathrm{WMB}_{10}\right)$ and maximum (62.63\%) was observed for control biscuits $\left(\mathrm{WMB}_{0}\right)$. The results are in agreement with those of Galla et al. (2017) who observed a decrease in the carbohydrate content from 62.14 to $54.35 \%$ using spinach powder as a supplement. A similar decreasing trend of carbohydrate content was also reported for biscuit supplemented with defatted groundnut paste (Dauda et al., 2018). The findings of Premi and Sharma (2018) also support the results of the present study who reported a decrease in the NFE (52.14-51.64\%) content of the bread supplemented with drumstick leaves powder. The reduction in the carbohydrate content may be the result of lower carbohydrate content of the moringa leaves powder.

\section{Sensory evaluation}

Color is the visual perception of a food product. The perception of color has pronounced effect on the taste and flavor of a product. The color score of biscuits is given in the Table 5 . The score of judges for color of the biscuits was maximum for control biscuits $\left(\mathrm{WMB}_{0}\right)$ which gradually decreased and was minimum for the biscuits supplemented with $10 \%$ moringa leaves powder. The color of biscuit with moringa leaves powder presented an unusual appearance. With a progressive increase in the level of moringa leaves powder, the color of biscuit become darker which decreased the sensory score but did not cause rejection of the cookies. The color of the biscuit changes from golden brown to brownish green (Figure 3). Our findings of the color score of the control and moringa enriched biscuits are in agreement with those of Galla et al. (2017) who reported a color score of 8.33 to 6.63 for spinach powder supplemented cookies. The results of the presented study are also supported by other researches. Batista et al. (2017) carried out a research on incorporation of green algae in cookies. According to their results the green color of the cookies presented an innovative and attractive appearance and was accepted by the consumer. The results of the present study are also in agreement with those of Gramza-Michałowska et al. (2016) who observed a significant change in the color score of green and yellow tea leaves supplemented cookies.

According to the mean score of judges the taste of the biscuits has higher score (7.73) for control biscuits $\left(\mathrm{WMB}_{0}\right)$ and a lower score (6.36) for the $10 \%$ moringa leaves supplemented biscuits $\left(\mathrm{WMB}_{10}\right)$. It is clear from the results that the score of taste has highest 
value for control which decreases with increasing level of moringa leaves supplementation. The results of the present study are in agreement with those of Galla et al. (2017), who reported the taste score of 8.25 to 6.21 for control and $10 \%$ spinach powder cookies. Hooda and Jood (2005) reported a decrease in the taste score of the cookies supplemented with fenugreek seed flour from 7.25 to 5 .

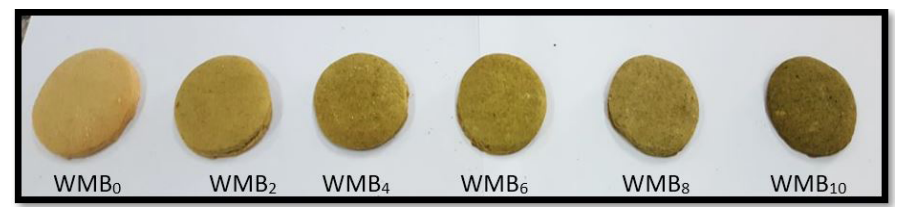

Figure 3: Images for color of control and supplemented biscuits.

Table 5: Sensory evaluation of control and supplemented biscuits.

$\begin{array}{lllll}\text { Treatment } & \text { Color } & \text { Taste } & \text { Texture } & \text { Overall acceptability } \\ \mathrm{WMB}_{0} & 7.86^{\mathrm{a}} & 7.73^{\mathrm{a}} & 7.84^{\mathrm{a}} & 7.81^{\mathrm{a}} \\ \mathrm{WMB}_{2} & 7.18^{\mathrm{ab}} & 7.50^{\mathrm{ab}} & 7.39^{\mathrm{ab}} & 7.35^{\mathrm{ab}} \\ \mathrm{WMB}_{4} & 7.06^{\mathrm{ab}} & 6.90^{\mathrm{abc}} & 7.23^{\mathrm{ab}} & 7.06^{\mathrm{bc}} \\ \mathrm{WMB}_{6} & 6.54^{\mathrm{bc}} & 6.74^{\mathrm{bc}} & 7.01^{\mathrm{ab}} & 6.76^{\mathrm{bcd}} \\ \mathrm{WMB}_{8} & 6.07^{\mathrm{c}} & 6.71^{\mathrm{bc}} & 6.92^{\mathrm{b}} & 6.57^{\mathrm{cd}} \\ \mathrm{WMB}_{10} & 5.71^{\mathrm{c}} & 6.36^{\mathrm{c}} & 6.77^{\mathrm{b}} & 6.28^{\mathrm{d}}\end{array}$

Different superscript letters within column with different letters in the column show significant difference at $5 \%$ level of significance. $W M B_{0}$ : biscuit with 100\% wheat flour; $W M B_{2}$ : biscuit with $98 \%$ wheat flour and 2\% Moringa leaves powder; $W M B_{4}$ biscuit with 96\% wheat flour and 4\% Moringa leaves powder; $\mathrm{WMB}_{6}$ : biscuit with 94\% wheat flour and 6\% Moringa leaves powder; $W M B_{8}$ : biscuit with 92\% wheat flour and 8\% Moringa leaves powderWMB $B_{10}$. biscuit with 90\% wheat flour and 10\% Moringa leaves powder.

The texture of the biscuit observed as the mean score of judges is shown in Table 5. The maximum score (7.84) for texture was recorded in control biscuits $\left(\mathrm{WMB}_{0}\right)$ which increased gradually, and the minimum score (6.54) was recorded for the biscuits supplemented with $10 \%$ moringa leaves powder $\left(\mathrm{WMB}_{10}\right)$. There was non-significant effect of moringa leaves powder up to $6 \%$ of enrichment level, but a higher level had significant impact on the texture of biscuit. Surface cracking was not observed in moringa leaves powder enriched biscuits (Figure 3). Our findings are in close agreement with those of Galla et al. (2017) who noted a texture score of 8.17 to 7.13 for control and $10 \%$ spinach powder supplemented cookies. They also a slight decrease in the texture score of the supplemented cookies. Hooda and Jood (2005) also noticed a decline in the texture score of the cookies supplemented with fenugreek seed flor from 7 to 5.94. A similar trend in the decrease of texture score of cookies was also observed by Sharif et al. (2009) who prepared cookies with defatted rice bran supplementation.

For overall acceptability control biscuits $\left(\mathrm{WMB}_{0}\right)$ received the highest score (7.81) whereas the biscuits supplemented with 10\% Moringa leaves powder (WMB10) received the lowest score (6.21). The mean score of judges for overall acceptability reveals that the acceptability of the biscuits decreased by the addition of moringa leaves powder. The overall acceptability of the biscuit decreased with the addition of moringa leaves powder but it can be seen that biscuit supplemented with 6\% moringa flour were nonsignificantly different from control biscuits whereas higher enrichment level of up to $10 \%$ scored $\approx 6$ on the hedonic scale which is rated slightly to moderately liked. This showed moderate consumer acceptability of the biscuits up-to $10 \%$ of enrichment level. This means that moringa leaves enriched biscuits could be widely appreciated and consumed functional food in the future. Our results for the overall acceptability of the biscuit is in line with those of Galla et al. (2017) who reported a score of 8.08 to 6.54 for the control and biscuit supplemented with $10 \%$ spinach powder. Similar results of overall acceptability (5.73-7.63) were also reported for cookies supplemented with green tea leaves (Gramza-Michałowska et al., 2016). Drisya et al. (2015) also concluded in their study of Murraya koenigii supplementation that the leaves could be supplemented up to a level of $10 \%$ without adversely affecting the physiochemical and sensorial attributes of the cookies.

\section{Conclusions and Recommendations}

Based on the results of moringa leaves powder it can be concluded that moringa may be used as a functional ingredient in food products. There was substantial increase in the fiber content, ash content and Protein content of biscuits supplemented with $10 \%$ moringa leaves powder. The sensory scores of the biscuit were also in the acceptable range. As there was $38.81 \%$ increase in the ash content of the biscuits, further study should be carried out to determine the individual mineral content of the biscuits.

\section{Novelty Statement}

The novelty of the research is that biscuits are supplemented with multi-nutrients i.e., ash, fiber and protein con-tent using a single, local source (moringa 
leaves) without any significant alteration to its sensory attributes, therefore, the current research might play a substantial role in overcoming the problem of food insecurity and malnutrition in the society.

\section{Author's Contribution}

Aysha Riaz designed the study, conducted experiments, interpreted results and drafted the manuscript. Said Wahab supervised the whole process and reviewed the manuscript.

\section{Conflict of interest}

The authors have declared no conflict of interest.

\section{References}

AACC, 2010. Approved methods of american association of cereal chemists. American Association of Cereal Chemists, St. Paul, MN.

Adeola, A.A. and E.R. Ohizua. 2018. Physical, chemical, and sensory properties of biscuits prepared from flour blends of unripe cooking banana, pigeon pea, and sweet potato. Food Sci. Nutr., 6(3): 532-540. https://doi.org/10.1002/ fsn3.590

Ajila, C., K. Leelavathi and U.P. Rao. 2008. Improvement of dietary fiber content and antioxidant properties in soft dough biscuits with the incorporation of mango peel powder. J. Cereal Sci., 48(2): 319-326. https://doi. org/10.1016/j.jcs.2007.10.001

Baljeet, S., B. Ritika and L. Roshan. 2010. Studies on functional properties and incorporation of buckwheat flour for biscuit making. Int. Food Res. J., 17(4).

Basman, A. and H. Köksel. 2001. Effects of barley flour and wheat bran supplementation on the properties and composition of turkish flat bread, yufka. Eur. Food Res. Tech., 212(2): 198202. https://doi.org/10.1007/s002170000241

Batista, A.P., A. Niccolai, P. Fradinho, S. Fragoso, I. Bursic, L. Rodolfi, N. Biondi, M.R. Tredici, I. Sousa and A. Raymundo. 2017. Microalgae biomass as an alternative ingredient in cookies: Sensory, physical and chemical properties, antioxidant activity and in vitro digestibility. Algal Res., 26: 161-171. https://doi. org/10.1016/j.algal.2017.07.017

Boukid, F., E. Zannini, E. Carini and E. Vittadini. 2019. Pulses for bread fortification: A necessity or a choice? Trends in Food Sci. Tech. https:// doi.org/10.1016/j.tifs.2019.04.007

Bradley, R.L., 2010. Moisture and total solids analysis. In Food analysis. Springer, pp. 85-104. https://doi.org/10.1007/978-1-4419-14781_6

Cheng, Y.F. and R. Bhat. 2016. Functional, physicochemical and sensory properties of novel cookies produced by utilizing underutilized jering (pithecellobium jiringa jack.) legume flour. Food Biosci., 14: 54-61. https://doi. org/10.1016/j.fbio.2016.03.002

Dachana, K., J. Rajiv, D. Indrani and J. Prakash. 2010. Effect of dried moringa (moringa oleifera lam) leaves on rheological, microstructural, nutritional, textural and organoleptic characteristics of cookies. J. Food Qual., 33(5): 660-677. https://doi.org/10.1111/j.17454557.2010.00346.x

Dauda, A.O., O.A. Abiodun, A.K. Arise and S.A. Oyeyinka. 2018. Nutritional and consumers acceptance of biscuit made from wheat flour fortified with partially defatted groundnut paste. LWT. 90: 265-269. https://doi.org/10.1016/j. lwt.2017.12.039

Díaz, A., R. Bomben, C. Dini, S.Z. Viña, M.A. García, M. Ponzi and N. Comelli. 2019. Jerusalem artichoke tuber flour as a wheat flour substitute for biscuit elaboration. LWT. https:// doi.org/10.1016/j.lwt.2019.03.082

Domenico, M., C. Lina and B. Francesca. 2018. Sustainable crops for food security: Moringa (Moringa oleifera Lam.). https://doi. org/10.1016/B978-0-08-100596-5.22574-2

Drisya, C., B. Swetha, V. Velu, D. Indrani and R. Singh. 2015. Effect of dried murraya koenigii leaves on nutritional, textural and organoleptic characeteristics of cookies. J. Food Sci. Tech., 52(1): 500-506. https://doi.org/10.1007/ s13197-013-1002-2

Ewulo, T., I. Oluwalana, B. Ewulo and O. Awolu. 2017. Enrichment of traditional maize snack (kokoro) with moringa (moringa oliefera) leaf and soybean. Afr. J. Food Sci., 11(5): 140-145.

Falowo, A.B., F.E. Mukumbo, E.M. Idamokoro, J.M. Lorenzo, A.J. Afolayan and V. Muchenje. 2018. Multi-functional application of moringa oleífera lam. In nutrition and animal food products: A review. Food Res. Int., 106:317-334. https://doi.org/10.1016/j.foodres.2017.12.079 Galla, N.R., P.R. Pamidighantam, B. Karakala, 
M.R. Gurusiddaiah and S. Akula. 2017. Nutritional, textural and sensory quality of biscuits supplemented with spinach (Spinacia oleracea L.). Int. J. Gastronomy Food Sci., 7: 2026. https://doi.org/10.1016/j.ijgfs.2016.12.003 Gammal, R., A. Gehan and E.S. Ghoneim. 2016. Effect of moringa leaves powder (Moringa oleifera) on some chemical and physical properties of pan bread. J. Food Dairy Sci., 7(7): 307-314. https://doi.org/10.21608/ jfds.2016.46005

Gandhi, A., N. Kotwaliwale, J. Kawalkar, D. Srivastav, V.Parihar and P.R. Nadh. 2001. Effect of incorporation of defatted soyflour on the quality of sweet biscuits. J. Food Sci. Technol., 38(5): 502-503.

Gramza-Michałowska, A., J. Kobus-Cisowska, D. Kmiecik, J. Korczak, B. Helak, K. Dziedzic and D. Górecka. 2016. Antioxidative potential, nutritional value and sensory profiles of confectionery fortified with green and yellow tea leaves (camellia sinensis). Food Chem., 211: 448-454. https://doi.org/10.1016/j. foodchem.2016.05.048

Hassanein, A.M.A., 2018. Nutritional, chemical and molecular characterisation of moringa oleifera lam. And moringa peregrina (forssk.) fiori genotypes. J. Hortic. Sci. Biotech., 93(5): 500-509. https://doi.org/10.1080/14620316.2 017.1399834

Hooda, S. and S. Jood. 2005. Organoleptic and nutritional evaluation of wheat biscuits supplemented with untreated and treated fenugreek flour. Food Chem., 90(3): 427-435. https://doi.org/10.1016/j. foodchem.2004.05.006

Ismail, T., S. Akhtar, M. Riaz and A. Ismail. 2014. Effect of pomegranate peel supplementation on nutritional, organoleptic and stability properties of cookies. Int. J. Food Sci. Nutr., 65(6): 661666. https://doi.org/10.3109/09637486.2014.9 08170

Kaur, M., V. Singh and R. Kaur. 2017. Effect of partial replacement of wheat flour with varying levels of flaxseed flour on physicochemical, antioxidant and sensory characteristics of cookies. Bioact. Carbohyd. Diet. Fibre, 9: 1420. https://doi.org/10.1016/j.bcdf.2016.12.002

Kulthe, A.A., V.D. Pawar, P.M. Kotecha, U.D. Chavan and V.V. Bansode. 2014. Development of high protein and low calorie cookies. J.
Food Sci. Tech., 51(1): 153-157. https://doi. org/10.1007/s13197-011-0465-2

Larmond, E., 1997. Laboratory methode for sensory evaluation of food product: Intersciense Publishing, New York.

Latunde-Dada, G.O., M.F. Aslam, P.R. Ellis, S.E. Berry and P.A. Sharp. 2019. Wheat flour fortification to prevent iron-deficiency anemia. In flour and breads and their fortification in health and disease prevention. Elsevier, pp. 485-491. https://doi.org/10.1016/B978-0-12814639-2.00039-3

Liu, S., S. Alavi and M. Abughoush. 2011. Extruded moringa leaf-oat flour snacks: Physical, nutritional, and sensory properties. Int. J. Food Prop., 14(4): 854-869. https://doi. org/10.1080/10942910903456358

Makkar, H. and K. Becker. 1996. Nutrional value and antinutritional components of whole and ethanol extracted moringa oleifera leaves. Anim. Feed Sci. Tech., 63(1-4): 211-228. https://doi. org/10.1016/S0377-8401(96)01023-1

Manley, D., 2011. Manley's technology of biscuits, crackers and cookies: Elsevier. https://doi. org/10.1533/9780857093646

Mendieta-Araica, B., E. Spörndly, N. ReyesSánchez and R. Spörndly. 2011. Feeding moringa oleifera fresh or ensiled to dairy cows effects on milk yield and milk flavor. Trop. Anim. Health Prod., 43(5): 1039-1047. https:// doi.org/10.1007/s11250-011-9803-7

Miller, R., R. Chavan, K. Sandeep, S. Bhatt, K. Tiefenbacher, C. Wrigley, S. Zydenbos, V. Humphrey-Taylor, C. Wrigley and S. Cauvain. 2016. Biscuits, cookies and crackers: Nature of the products.

Murwa, K., A. Ndhlala, H. Abdelgadir, J. Finnie and J. Van Staden. 2017. Influence of cultivation practices on nutrition and phytochemicals of moringa oleifera lam. South Afr. J. Bot., 100(109): 357. https://doi.org/10.1016/j. sajb.2017.01.135

Narwal, S., O.P. Gupta, V. Pandey, D. Kumar and S. Ram. 2020. Effect of storage and processing conditions on nutrient composition of wheat and barley. In wheat and barley grain biofortification. Elsevier, pp. 229-256. https:// doi.org/10.1016/B978-0-12-818444-8.000092

Nasir,M., M.Siddiq, R. Ravi,J. Harte, K. Dolan and M. Butt. 2010. Physical quality characteristics 
and sensory evaluation of cookies made with added defatted maize germ flour. J. Food Qual., 33(1): 72-84. https://doi.org/10.1111/j.17454557.2009.00291.x

Nogueira, A.D.C. and C.J. Steel. 2018. Protein enrichment of biscuits: A review. Food Rev. Int., 34(8): 796-809. https://doi.org/10.1080/8 7559129.2018.1441299

Nouman, W., F. Anwar, T. Gull, A. Newton, E. Rosa and R. Domínguez-Perles. 2016. Profiling of polyphenolics, nutrients and antioxidant potential of germplasm's leaves from seven cultivars of Moringa oleifera lam. Indus. Crops Prod., 83: 166-176. https://doi.org/10.1016/j. indcrop.2015.12.032

Ocheme, O.B., O.E. Adedeji, C.E. Chinma, C.M. Yakubu and U.H. Ajibo. 2018. Proximate composition, functional, and pasting properties of wheat and groundnut protein concentrate flour blends. Food Sci. Nutr., 6(5): 1173-1178. https://doi.org/10.1002/fsn3.670

Pande, S., S. Sakhare, M. Bhosale, D. Haware and A. Inamdar. 2017. Atta (whole wheat flour) with multi-wholegrains: Flour characterization, nutritional profiling and evaluation of chapati making quality. J. Food Sci. Techn., 54(11): 3451-3458. https://doi.org/10.1007/s13197017-2801-7

Premi,M. and H. Sharma.2018. Effect of drumstick leaves powder on the rheological, microstructural and physico-functional properties of sponge cake and batter. J. Food Meas. Charact., 12(1): 11-21. https://doi.org/10.1007/s11694017-9612-4

Rajiv, J., S. Lobo, A. Jyothi-Lakshmi and G.V. Rao. 2012. Influence of green gram flour (phaseolus aureus) on the rheology, microstructure and quality of cookies. J. Texture Stud., 43(5): 350-360. https://doi.org/10.1111/j.17454603.2012.00346.x

Rebellato, A.P., B.C. Pacheco, J.P. Prado and J.A.L. Pallone. 2015. Iron in fortified biscuits: A simple method for its quantification, bioaccessibility study and physicochemical quality. Food Res. Int., 77: 385-391. https://doi.org/10.1016/j. foodres.2015.09.028

Rosell, C., 2012. Nutritionally enhanced wheat flours and breads. In Breadmaking. Elsevier, pp. 687-710. https://doi. org/10.1533/9780857095695.4.687

Sánchez-Machado, D.I., J.A. Núñez-Gastélum,
C. Reyes-Moreno, B. Ramírez-Wong and J. López-Cervantes. 2010. Nutritional quality of edible parts of moringa oleifera. Food Anal. Methods, 3(3): 175-180. https://doi. org/10.1007/s12161-009-9106-Z

Sharif,M.K.,M.S.Butt, F.M. Anjum and H.Nawaz. 2009. Preparation of fiber and mineral enriched defatted rice bran supplemented cookies. Pak. J. Nutr., 8(5): 571-577. https://doi.org/10.3923/ pjn.2009.571.577

Sharma, P., V. Velu, D. Indrani and R. Singh. 2013. Effect of dried guduchi (Tinospora cordifolia) leaf powder on rheological, organoleptic and nutritional characteristics of cookies. Food Res. Int., 50(2): 704-709. https://doi.org/10.1016/j. foodres.2012.03.002

Shokery, E., M. El-Ziney, A. Yossef and R. Mashaly. 2017. Effect of green tea and moringa leave extracts fortification on the physicochemical, rheological, sensory and antioxidant properties of set-type yoghurt.J.Adv. Dairy Res., 5(179): 2 . https://doi.org/10.4172/2329-888X.1000179

Srivastava, P., D. Indrani and R. Singh. 2014. Effect of dried pomegranate (punica granatum) peel powder (dppp) on textural, organoleptic and nutritional characteristics of biscuits. Int.. J. Food Sci. Nutr., 65(7): 827-833. https://doi.org $/ 10.3109 / 09637486.2014 .937797$

Steel, R.G. and J.H. Torrie. 1960. Principles and procedures of statistics. Principles and procedures of statistics.

Sudha, M., R. Vetrimani and K. Leelavathi. 2007. Influence of fibre from different cereals on the rheological characteristics of wheat flour dough and on biscuit quality. Food Chem., 100(4): 1365-1370. https://doi.org/10.1016/j. foodchem.2005.12.013

Turfani, V., V. Narducci, A. Durazzo, V. Galli and M. Carcea. 2017. Technological, nutritional and functional properties of wheat bread enriched with lentil or carob flours. LWT-Food Sci. Tech., 78: 361-366. https://doi.org/10.1016/j. lwt.2016.12.030

Villemejane, C., P. Roussel, S. Berland, P. Aymard and C. Michon. 2013. Technological and sensory tools to characterize the consistency and performance of fibre-enriched biscuit doughs. J. Cereal Sci., 57(3): 551-559. https:// doi.org/10.1016/j.jcs.2013.03.005

Yaméogo, C.W., M.D. Bengaly, A. Savadogo, P.A. Nikiema and S.A. Traore. 2011. Determination 
of chemical composition and nutritional values of moringa oleifera leaves. Pak. J. Nutr., 10(3): 264-268. https://doi.org/10.3923/ pjn.2011.264.268

Zhang, H., H. Wang, X. Cao and J. Wang. 2018. Preparation and modification of high dietary fiber flour: A review. Food Res. Int., 113: 24-35. https://doi.org/10.1016/j.foodres.2018.06.068 